\title{
SIMILARITIES AND DIFFERENCES OF SPOKEN AND WRITTEN LANGUAGE
}

\author{
Umida Kulmagambetovna Khodjaniyazova
}

Postgraduate Student, Nukus State Pedagogical Institute, Republic Uzbekistan

\section{ABSTRACT}

This article deals with linguistic and pragma linguistic view of speaking and writing competence, and explores the similarities and differences between them. The definition of a "linguistic personality" as a key factor in product creation is discussed. Moreover, the article provides the examples that show the difference between written and spoken language in the field of syntax.

KEYWORDS: - Written language, spoken language, psychophysiological process, linguistic, pragma linguistic, linguistic personality.

\section{INTRODUCTION}

It is no coincidence that in our country from the 2013-2014 academic year, foreign languages are studied at all stages of continuing education, starting from grade 1 . Foreign language learning is a priority in the Republic of Uzbekistan, striving for the commonwealth and cooperation with foreign partners, which was defined in the Message to the Oliy Majlis of the President of the Republic of Uzbekistan Shavkat Miromonovich Mirziyoyev dated December 22, 2017: "We will continue to give priority to the in-depth study of English and other foreign languages. At the same time, we will establish extensive work on training and professional staff development in specialties that is in demand in our country "[Message ..., 2017, p. 2].

According to the requirements of the State Educational Standard for Foreign Languages of the Continuing Education System of the Republic of Uzbekistan, the content of written competence for graduates of primary (1-4) grades is level A1

At the next levels ( $A 2$ for graduates of the 9th grade, B1 for college/lyceum graduates, B2 for Bachelor graduates of non-linguistic faculties of higher education and $\mathrm{C} 1$ for graduates of language faculties of higher educations), students' writing skills gradually become more complicated and at the same time their vocabulary is enriched, and of course the amount of topics and information for communication expands.

The main goal of teaching a foreign language at all steps of education in the Republic of Uzbekistan is the development of a foreign language communicative competence of students for functioning in a multicultural world in everyday, scientific and professional spheres.

But in order to be a good and effective 
CURRENT RESEARCH JOURNAL OF PEDAGOGICS 2(8): 20-23, August

2021 DOI: https://doi.org/10.37547/pedagogics-crjp-02-08-06

ISSN 2767-3278

(C)2021 Master Journals

\section{Crossref do) 81 Google}

Accepted 22 th August, 2021 \& Published 27thAugust, 2021

communicator and to develop a foreign language communicative competence, all four basic language skills (listening, reading, speaking and writing) must be developed. Among these basic types, writing is the least meaningful in theory. However, it should be pointed that one of the important components of teaching English at educational institutions of the Republic of Karakalpakstan is the development of foreign language written competence.

Written language is the most complex type of speech, which is due to the presence of a whole range of skills and abilities and includes writing techniques (graphics, spelling, calligraphy) and the creation of a speech product - written text.

When referring to the writing technique, then this is a complex psychophysiological process, in which auditory, speech-motor, visual-graphic, motor analyzers are involved.

Additionally, writing is closely related to all other types of speech activity. The process of generating written language is implicitly accompanied by the processes of reading, pronouncing "to oneself" of the written text.

Sometimes writing is preceded or accompanied by listening. This implies a number of proper linguistic and pragma linguistic similarities and differences between spoken and written language. We need to compare them in order to develop a more consistent understanding of the nature of such phenomenon as written language.

Accordingly, there are both similarities and differences between spoken and written language. The similarity we have noted is a consequence of the identity of their nature: both oral and written languages are the implementation of the literary language as a system of signs intended for communication, collection, storage and transmission of information, impact, expression of emotions and feelings, creation of works of art, etc.

The key factor in the creation of works of both oral and written language is the linguistic personality. Note that the concept of "linguistic personality" is used in many areas of humanitarian knowledge (linguistics, cultural studies, linguodidactics, etc.), characterized by a wide variability of interpretations.

Of all this variety, we are close to the definition that was proposed by G.I. Bogin: "The central concept of linguodidactics is a linguistic personality - a person analyzed from the point of view of his readiness to perform speech acts. $<\ldots>$ A linguistic person is the one who appropriates the language, that is, the one for whom language is speech. A linguistic person is characterized not so much by what he knows about the language as by what he can do with the language "[Bogin, 1980, p. 3].

To the same extent, we are impressed by the definition proposed by the culturologist E.V. Barsukova: "A linguistic personality is a multidimensional, multilevel functional system that gives an idea of the degree of language and speech proficiency by an individual at the level of active and creative comprehension of reality" (E. V. Barsukova, 2007, p. 5].

Based on these definitions, we can say that a linguistic personality is an accent of speech, and to the extent that the given language is familiar to it.

In terms of the degree of penetration into various spheres of the life of the individual and society (the sphere of everyday relations, science, religion, production, management, education, jurisprudence, art, in the media, etc.), spoken and written languages are generally the same, although they are represented in them in various proportions.

For instance, in the sphere of everyday 
CURRENT RESEARCH JOURNAL OF PEDAGOGICS 2(8): 20-23, August

2021 DOI: https://doi.org/10.37547/pedagogics-crjp-02-08-06

ISSN 2767-3278

(C)2021 Master Journals

\section{Crossref do) 81 Google}

Accepted 22 ${ }^{\text {th }}$ August, 2021 \& Published 27 ${ }^{\text {th }}$ August, 2021

communication, spoken language dominates (in terms of quantitative characteristics), while written language is presented here sporadically. On the contrary, the language of fiction arises in the form of written language, which only then can acquire a spoken form. However, be that as it may, any work of speech, regardless of genre and stylistic coloring, can be presented both in spoken or written form. Finally, both forms can equally serve as indicators of the general culture of a particular linguistic personality and the level of its intellectual and spiritual development.

The following can be said regarding the differences between spoken and written languages. Firstly, there are differences between spoken and written languages in the means of material expression and in relation to time and space. If spoken language unfolds in time as a series of linearly located sound complexes endowed with meaning, then written language unfolds in space as a series of equally meaningful and linearly located graphic complexes.

Thus, written language is relatively independent of the moment of speech, since once recorded, it becomes, as it were, timeless. Of course, this phenomenon has more culturological significance rather than linguistic, but it cannot but affect the essential properties of written language: it is characterized, in comparison with spoken language, by greater preparedness to (thoughtfulness) and more consistent and conscious adherence to literary norms.

Another consequence of this is that there are a number of syntax differences. The syntax of spoken language avoids complex syntactic constructions consisting of three or more predicative parts.

At the same time, it:

1) tends to ellipsis (i.e. various incomplete syntactic constructions, such as interrogative sentences without a subject) for example:
- Been here long? (Have you ...) - Yes, two hours already.

- You actually leaving tomorrow? (Are you ...)

2) tends to the so-called typed constructions, which in English colloquial speech include cases of missing a personal pronoun and an auxiliary verb, for example:

- See you tomorrow. (I shall ...)

- Hope I didn't disturb you? (I ...)

3) gravitates towards the active use of wordssentences, for example:

- Are you fond of skating? - Very.

- Is that clear? - Quite.

- Silence!

In contrast, the syntax of writing is much more complex. Moreover, it can be argued without any stretch that the accumulation of almost all the richness of the syntax of the literary language was possible solely thanks to written language. This is due to the above-mentioned thoughtfulness and greater preparedness of written statements. In addition, written language, in contrast to spoken language, is characterized by independence from the physiological processes of human respiration, which removes many of the quantitative restrictions from it.

To what has been said, it should be added that written language is almost always a creative process that requires significant intellectual effort, tension of imagination, abstract thinking, etc. Written text, regardless of its quality, is perceived by the writer as the result of the realization of his creative potential, as something that largely reflects the personality of the author.

All this greatly complicates the process of 
CURRENT RESEARCH JOURNAL OF PEDAGOGICS 2(8): 20-23, August

2021 DOI: https://doi.org/10.37547/pedagogics-crjp-02-08-06

ISSN 2767-3278

(C)2021 Master Journals

Crossref dof 81 Google

Accepted 22 th August, 2021 \& Published 27thAugust, 2021

acquiring the skill of writing and not only makes it a derivative function of other types of roaring activity, but also translates writing from among speech acts into the category of acts of psychological, and finally, acts of culture. Admittedly, this circumstance imposes certain obligations on the teacher, whose task is to develop students' both the writing technique and some creative abilities.

Therefore, work on the developing of writing skills should be carried out both with the aim of studying the norms of written language, and taking into account the structural and psychological characteristics of writing as a productive type of speech activity.

\section{ReFERENCES}

1. Message of the President of the Republic of Uzbekistan Shavkat Mirziyoyev to the Oliy Majlis of December 22, 2017 // Pravda Vostoka, December 23, 2017.- No. 248 (28706). - S. 2.

2. State educational standard in foreign languages of the system of continuing education

3. Barsukova E.V. Language personality as a category of historical culturology: on the basis of the "Archives of Prince Vorontsov": Abstract of the thesis. ... candidate of cultural studies: 24.00.01 / Barsukova Elena Viktorovna; [Place of protection: Mosk. state. un-t them. M.V. Lomonosov]. - Moscow, 2007. -22

4. Bogin G.I. Modern linguodidactics. Kalinin: Kalinin. state un-t, 1980.61

5. Rasuljanovna, I. N. (2020). The concept of "lacuna" in translation studies. Asian Journal of Multidimensional Research (AJMR), 9(4), 123-129.

6. Usmanova, S. R., \& Ismatullayeva, N. R.
(2020). Expression Of Lacunas In Comparative Study Of Kinship Terms In Chinese And Uzbek Languages. Solid State Technology, 63(6), 4974-4985.

7. Rasuljanovna, I. N. (2019). THE PHENOMENON OF LACUNARITY AS THE LINGUACULTURAL ISSUE. PROSPECTS OF WORLD SCIENCE-2019, 226.

8. Parhadjanovna, S. S. (2020). English and uzbek meat idioms reflected by culture and history. ACADEMICIA: An International Multidisciplinary Research Journal, 10(5), 832-836. 